\title{
PERSONAL HIGIENE TERHADAP KONTAMINASI BAKTERI Salmonella sp PADA ES CAMPUR
}

\author{
Normalisa Ella Yunarti, Rahmawati, Erminawati \\ Poltekkes Kemenkes Banjarmasin Jurusan Kesehatan Lingkungan \\ Jalan H. Mistar Cokrokusumo No. 1A Banjarbaru Kalimantan Selatan \\ Email: normalisa.yunarti@gmail.com
}

\begin{abstract}
Personal Hygiene toward The Contamination of Salmonella sp Bacteria in Mixed Ice. Mixed ice is a beverage that is very popular with people and is very easy to find. Traders mixed ice that their hygiene is not quite right; it is very easily contaminated by pathogen bacteria. Landasan Ulin District as a trading centre in Kota Banjarbaru makes it strategic place so many mixed ice traders found in this District. This study was aiming to determine the traders mixed ice's hygiene with the contamination of Salmonella sp bacteria in blended ice. This type of research was an analytical survey with a cross-sectional study design. Data were collected by observing, interviewing and examining samples, as many as 23 mixed ice samples were analysing of salmonella sp bacteria. Data analysis was performing using Somer's d correlation test. The results showed that there was a significant correlation between personal hygiene of mixed ice traders with Salmonella sp bacteria with a negative correlation direction which could be a conclusion that the higher the personal hygiene score of combined ice traders, the Salmonella sp bacteria would be harmful in mixed ice. It is suggested to the next researcher to check the Salmonella sp bacteria on each component of blended ice so that they will know at what stage Salmonella sp bacteria have contaminated the ice mixed.
\end{abstract}

Keywords: Personal Hygiene; Salmonella sp Bacteria; Mixed Ice

\begin{abstract}
Abstrak: Personal Higiene terhadap Kontaminasi Bakteri Salmonella sp pada Es Campur. Es campur merupakan makanan jajanan yang sangat digemari masyarakat dan sangat mudah ditemukan. Pedagang es campur yang personal higiene buruk dapat menyebabkan kontaminasi bakteri pathogen pada es campur. Kecamatan Landasan Ulin sebagai sentral perdagangan di Kota Banjarbaru menjadikannya tempat yang strategis sehingga banyak ditemukan pedagang es campur Penelitian ini bertujuan untuk mengetahui hubungan personal higiene dengan kontaminasi bakteri Salmonella sp pada es campur. Jenis penelitian ini bersifat survei analitik dengan desain Cross Sectional Study. Data dikumpulkan dengan metode observasi, wawancara dan pemeriksaan sampel, sampel es campur sebanyak 23 dilakukan pemeriksaan bakteri Salmonella sp di Laboratorium. Analisis data dilakukan menggunakan uji korelasi somer's d. Hasil penelitian menunjukkan terdapat korelasi yang bermakna antara personal higiene pedagang es campur dengan bakteri Salmonella sp dengan arah korelasi negatif yang dapat disimpulkan bahwa, semakin tinggi skor personal higiene pedagang es campur maka kandungan bakteri Salmonella sp akan negatif dalam es campur. Pedagang es campur yang tidak mencuci tangan saat mengolah es campur serta tidak menggunakan celemek menyebabkan sebagian besar es campur terkontaminasi bakteri Salmonella sp. Disarankan kepada peneliti selanjutnya untuk melakukan pemeriksaan bakteri Salmonella sp terhadap setiap komponen es campur sehingga mengetahui pada tahapan mana es campur sudah terkontaminasi oeh bakteri Salmonella sp.
\end{abstract}

Kata Kunci: Personal Higiene; Bakteri Salmonella sp; Es Campur

\section{PENDAHULUAN}

Es campur banyak dikonsumsi oleh masyarakat dan cukup menjadi penghilang dahaga yang harganya relatif murah sehingga dapat terjangkau oleh berbagai lapisan masyarakat. Es campur merupakan minuman yang dijual tanpa kemasan khusus, diproduksi dan dipersiapkan ditempat penjualannya sehingga sulit dilakukan pengawasan terhadap mutunya ${ }^{[1]}$. 
Berdasarkan hasil pengujian yang dilakukan oleh Badan POM pada tahun 2012 dan 2013 menunjukkan bahwa minuman es, seperti es mambo, es cendol dan es campur, yang beredar di sekolahsekolah di Indonesia sebanyak 46,67\% pada tahun 2012 dan $40,54 \%$ pada tahun 2013 tidak memenuhi syarat ${ }^{2]}$.

Es campur yang dijual pedagang kaki lima di Pasar Minggu Kelurahan Belakang Pondok Kecamatan Gading Cempaka Bengkulu, diketahui bahwa es campur tidak memenuhi persyaratan kualitas bakteriologis[3]. Sedangkan es campur di kompleks pasar 45 Kota Manado diketahui bahwa (70\%) es campur tidak memenuhi persyaratan kualitas bakteriologis [1].

Perilaku penjamah makanan yang kurang dalam memperhatikan personal hygiene yang tidak baik juga dapat menyebabkan kontaminasi bakteri pada makanan ${ }^{[4]}$.

Kecamatan Landasan Ulin merupakan salah satu Kecamatan strategis yang menjadikannya sebagai salah satu sentral perdagangan di Kota Banjarbaru. Berdasarkan hasil survei pendahuluan yang dilakukan, ada sebanyak 44 pedagang es campur di Kecamatan Landasan Ulin. Jumlah ini paling banyak di bandingkan dengan 4 Kecamatan lain yang ada di Kota Banjarbaru. Berkaitan dengan hal itu, minuman es campur berpotensi terkontaminasi oleh bakteri pathogen apabila personal higiene pedagang es campur buruk.

\section{BAHAN DAN CARA PENELITIAN}

Jenis penelitian ini bersifat survei analitik, yaitu menghubungkan antara personal higiene pedagang dengan kualitas bakteri salmonella sp pada es campur. Desain penelitian ini menggunakan pendekatan Cross Sectional Study sedangkan analisis bivariat menggunakan uji somers'd.

Populasi penelitian adalah seluruh es campur yang dijual di Kecamatan Landasan Ulin Kota Banjarbaru yang berjumlah 44 es campur, sampel es campur yang dilakukan pemeriksaan yaitu sebanyak 23 es campur. Metode pengambilan sampel dilakukan dengan simple random sampling.

Instrumen yang digunakan dalam penelitian ini yaitu lembar observasi yang diisi oleh peneliti kemudian sampel es campur dilakukan pemeriksaan bakteri Salmonella sp di Laboratorium Mikrobiologi Jurusan Kesehatan Lingkungan Poltekkes Kemenkes Banjarmasin.

\section{HASIL PENELITIAN DAN PEMBAHASAN}

Observasi yang dilakukan oleh peneliti terhadap 23 pedagang es campur yang berdagang di Kecamatan Landasan Ulin, sebagian besar berdagang di pinggiran Jalan Ahmad Yani dengan waktu berdagang yang dimulai pukul 09.00 sampai dengan 17.00 WITA.

Tabel 1. Personal Higiene Pedagang Es Campur

\begin{tabular}{|c|c|c|c|}
\hline \multirow{2}{*}{ No } & \multirow{2}{*}{ Personal Higiene } & \multicolumn{2}{|c|}{ Jumlah Warung Yang Melakukan Tindakan } \\
\hline & & $\mathrm{Ya}$ & Tidak \\
\hline 1. & $\begin{array}{l}\text { Tidak menderita penyakit mudah menular seperti } \\
\text { batuk, influenza dan diare }\end{array}$ & 23 & 0 \\
\hline 2. & $\begin{array}{l}\text { Tidak terdapat luka terbuka dan bisul bernanah pada } \\
\text { kulit }\end{array}$ & 22 & 1 \\
\hline 3. & $\begin{array}{l}\text { Mencuci tangan setiap kali hendak menangani } \\
\text { minuman }\end{array}$ & 3 & 20 \\
\hline 4. & $\begin{array}{l}\text { Menggunakan alat atau dengan a las tangan ketika } \\
\text { hendak menjamah makanan }\end{array}$ & 19 & 4 \\
\hline 5. & Berpakaian bersih & 23 & 0 \\
\hline 6. & Memakai celemek & 0 & 23 \\
\hline 7. & Memakai penutup kepala & 12 & 11 \\
\hline 8. & Tidak merokok saat menjamah makanan & 21 & 2 \\
\hline 9. & Kuku tidak panjang dan bersih & 17 & 6 \\
\hline 10. & Tidak memakai perhiasan ditangan & 7 & 16 \\
\hline
\end{tabular}


11. Tidak menggaruk anggota badan saat bekerja (telinga, hidung, mulut, rambut atau bagian lainnya)

12. Tidak batuk atau bersin dihadapan minuman yang disajikan atau tanpa menutup mulut

7

4
Berdasarkan tabel 1 diketahui semua pedagang es campur dalam kondisi sehat, tidak menderita penyakit menular seperti batuk, pilek, influenza dan diare. Hanya 3 pedagang es campur yang mencuci tangan setiap kali hendak menangani es campur dan tidak ada satupun pedagang es campur yang menggunakan celemek.

Tabel 2. Distribusi Kategori Personal Higiene Pedagang Es Campur dan Kualitas Bakteriologis Es Campur

\begin{tabular}{clcc}
\hline \multirow{2}{*}{ No. } & \multirow{2}{*}{ Kategori Personal Higiene } & \multicolumn{2}{c}{ Kontaminasi Bakteri Salmonella sp } \\
& & Positif & Negatif \\
\hline 1. & Baik & 0 & 3 \\
2. & Cukup & 15 & 0 \\
3. & Kurang & 5 & 0 \\
\multicolumn{2}{r}{ Jumlah } & 20 & 3 \\
\hline
\end{tabular}

Tabel 2 menunjukkan 3 pedagang dengan kategori personal higiene baik tidak ditemukan bakteri Salmonella $s p$ pada es campur yang dijualnya sedangkan pedagang dengan kategori personal higiene cukup dan kurang ditemukan bakteri Salmonella sp pada es campur yang dijualnya.

Tabel 3. Korelasi Personal Higiene Pedagang Es Campur dan Bakteri Salmonella Sp pada Es Campur

\begin{tabular}{|c|c|c|c|c|c|c|}
\hline & & Direc & nal Measu & & & \\
\hline & & & Value & $\begin{array}{c}\text { Asymp. Std. } \\
\text { Error }^{\mathrm{a}}\end{array}$ & $\begin{array}{c}\text { Approx. } \\
\mathrm{T}^{\mathrm{b}}\end{array}$ & Approx. Sig. \\
\hline Ordinal by Somers' d & Symmetric & &,- 020 & ,172 &,- 117 & ,907 \\
\hline Ordinal & PERSONAL & &,- 033 & 285 &,- 117 & 907 \\
\hline & $\begin{array}{l}\text { HIGIENE } \\
\text { PEDAGANG }\end{array}$ & ES & & & & \\
\hline & CAMPUR & & & & & \\
\hline & Dependent & & & & & \\
\hline & BAKTERI & &,- 014 & 123 &,- 117 & 907 \\
\hline & SALMONELLA & SP & & & & \\
\hline tassuming the null hyn & $\begin{array}{l}\text { Dependent } \\
\text { hesis. }\end{array}$ & & & & & \\
\hline
\end{tabular}

Berdasarkan tabel 3 hasil analisis statistik menggunakan uji korelasi somer's $d$ di dapatkan hasil nilai $\mathrm{p}=-0,033 \geq$ nilai $\alpha=0,05$. Berdasarkan hasil ini maka Ha diterima, sehingga disimpulkan secara statistik terdapat korelasi yang bermakna antara dua variabel yang diuji. Berdasarkan hal itu maka ada hubungan antara personal higiene pedagang es campur dengan bakteri Salmonella $s p$ pada es campur, dengan arah korelasi negatif dapat di simpulkan bahwa, semakin tinggi skor personal higiene pedagang es campur maka kandungan bakteri Salmonella $s p$ akan negatif dalam es campur.

Seluruh pedagang es campur tidak menggunakan celemek padahal fungsi menggunakan celemek untuk menghindari makanan dari pencemaran. Pedagang dengan jenis kelamin perempuan masih banyak yang menggunakan perhiasan 
ditangan seperti cincin, perilaku ini dapat memperbesar kemungkinan terjadinya kontaminasi pada es campur. 3 orang pedagang es campur yang selalu mencuci tangan sebelum melakukan pengolahan es campur juga tidak mengenakan perhiasan seperti cincin membuktikan bahwa es campur yang diolahnya negatif dari bakteri Salmonella sp. Banyak infeksi yang ditularkan melalui penjamah makanan, antara lain bakteri Salmonella yang dapat ditularkan melalui kulit. Penjamah makanan juga dapat bertindak sebagai carrier (pembawa) penyakit infeksi seperti demam typoid, hepatitis A dan diare $^{[5]}$

\section{KESIMPULAN DAN SARAN}

Pedagang es campur tidak mencuci tangan saat hendak melakukan pengolahan es campur, tidak menggunakan celemek dan menggunakan perhiasan seperti cincin merupakan penyebab utama terkontaminasinya es campur oleh bakteri Salmonella sp.

Melakukan pemeriksaan bakteri Salmonella sp terhadap setiap komponen es campur sehingga mengetahui pada tahapan mana es campur sudah terkontaminasi oeh bakteri Salmonella sp.

\section{KEPUSTAKAAN}

1. JURNAL-PUBLIKASI-CHYNTIA-G.LUMATAUW.pdf.

2. BPOM. Laporan Kinerja Badan Pengawas Obat dan Makanan. Jakarta: 2012.

3. Sitohang K. Pengelolaan dan Kandungan Bakteri Escherichia coli pada Es Campur. Sumatera Utara: Universitas Sumatera Utara; 2003.

4. Sucipto DC. Keamanan Pangan Untuk Kesehatan Manusia. Yogyakarta: 2016.

5. Fitriani A. Studi Gambaran Higiene Sanitasi Pedagang dan Keberadaan Escherichia coli Pada Es buah di Kota Salatiga. Semarang: Universitas Negeri Semarang; 2016. 